\title{
The Friendship Between Sigmund Freud and Oskar Pfister as Seen in the Correspondence between the Jewish Atheist Founder of Psychoanalysis and the Swiss Pastor Who Pioneered Pastoral Psychology
}

\author{
Isabelle Noth • Christoph Morgenthaler
}

Published online: 1 August 2013

(C) Springer Science+Business Media New York 2013

\begin{abstract}
The new edition of the correspondence between Sigmund Freud and Oskar Pfister (Noth 2013) offers new insights on the extraordinary and hitherto not well-known 30-year literary friendship between the Vienna-based founder of psychoanalysis and the Zurichbased founder of pastoral psychology. The selection published by Ernst L. Freud and Heinrich Meng in 1963 by Fischer-Verlag, which also appeared in an English translation that same year published by Basic Books, New York, did not contain all the letters between Freud and Pfister and included only excerpts of some. The discovery of a typescript of the correspondence between Pfister and Freud sheds new light on the friendship between these two men.
\end{abstract}

Keywords Psychoanalysis · Pastoral psychology · Sigmund Freud · Oskar Pfister · Religion

When the Swiss pastor Oskar Pfister visited Sigmund Freud the very first time in Vienna in April 1909, he took - like guests do - a little gift with him: a silver model of one of the world's most famous mountains, the Matterhorn. Pfister loved to hike in the Alps, and he told Freud's children about his mountain tours. They were so fascinated that Freud explicitly mentioned Pfister's powerful impact on them, and when you listen to Freud's words, he almost seemed to be a bit jealous of Pfister:

I do not know what promises you left behind with my children, because I keep hearing things like next year I'm going with Dr Pfister, I'm going climbing with him, and so on and so forth. I dare not mention your 10,000-foot climb with your son, because it would rouse my boys' blackest envy, they would wish they had a father like you, who could still climb with them instead of . . p picking strawberries in the woods down below. (letter from Freud to Pfister, August 16, 1909, in Freud and Pfister 1963, p. 27)

I. Noth $(\bowtie) \cdot C$. Morgenthaler

Theology Faculty, University of Bern, Unitobler, Länggassstrasse 51, CH-3000 Bern 9, Switzerland e-mail: isabelle.noth@theol.unibe.ch

C. Morgenthaler

e-mail: christoph.morgenthaler@theol.unibe.ch 
The Matterhorn, the Swiss mountains were a kind of symbolic entry ticket for Pfister into the heart and mind of Freud and his family.

In his letter to Pfister in May 1909-1 month after Pfister's first visit—Freud wrote:

\section{Dear Dr Pfister,}

The Matterhorn now crowns the pile of unanswered letters on my desk. I gladly accept the small fragment of Switzerland in the symbolic sense you suggest, as homage from the only country in which I feel a man of property, knowing that the hearts and minds of good men there are well disposed towards me. I have no intention of defending myself. I have deliberately set myself up only as an example, but never as a model, let alone an object of veneration. The Matterhorn can easily be given another and more modest meaning. The proportion of one to 50,000 may be roughly that in which fate fulfils our wishes and we ourselves fulfil our intentions. Incidentally it has struck me how little figures mean to our imagination; I have the greatest difficulty in believing that one would have to put only 50,000 of these small objects on top of one another to reach the height of a huge mountain. I should have guessed that more than a million would have been required.

I propose to endow the Matterhorn with yet a third meaning. It reminds me of a remarkable man who came to see me one day, a true servant of God, a man in the very idea of whom I should have had difficulty in believing, in that he feels the need to do spiritual good to everyone he meets. You did good in this way even to me. (letter from Freud to Pfister, May 10, 1909, in Freud and Pfister 1963, p. 24, emphasis added)

These were the words of Freud in 1909 after Pfister's first visit. In Webster's thesaurus the English word "remarkable" has the meaning of "worthy of notice; extraordinary". But the German word Freud used-merkwürdig - has a double meaning: "remarkable" in the sense of worthy of notice and extraordinary, but it also has the meaning of "a bit odd", almost a bit "nuts".

Now, "remarkable" is not just a good word for Freud's perception of Pfister, obviously, but also for the friendship of these two men-it's truly a remarkable friendship in both senses of the word. It is a notable friendship and a friendship a bit like "the odd couple"! We intend to show why and how remarkable this friendship was-what is new is that we can do this on the basis of newly found letters between Freud and Pfister.

In the first part, we will say a few words about Pfister and the detective story behind the recently found letters that led to the new edition of the correspondence between Freud and Pfister that will be out soon (Noth 2013). Then we will deal with the question about the remarkable friendship between the Jewish atheist Freud and the Protestant pastor Pfister by focusing on the question of religion.

\section{Oskar Pfister (1873-1956)}

Pfister definitively was the first theologian to realize how meaningful Freud's work and psychoanalysis could be for theology. He applied psychoanalytic thinking to pastoral care and published his first articles on psychoanalysis as early as 1908. Just for the sake of understanding the time-line, Boisen was introduced to Freud in 1920 (Boisen 1960, p. 3).

Pfister was born near Zurich in 1873 as the youngest of four sons. This means he was almost the same age as Boisen, who was born in 1876. His father was a pastor and then decided to study medicine, but he died when Pfister was 3 years old. His mother moved with her four sons to the Moravian Königsfeld in Germany where Albert Schweitzer, his friend 
whom he introduced to psychoanalysis (Noth 2007, 2008), later lived. The family moved back to Zurich, where Pfister studied theology and philosophy (he also studied in Basel and Berlin). In 1897 he finished his doctorate, got married, and 1 year later had a son-Oskar Robert Pfister-who became a psychiatrist.

Pfister several times was offered a professorship-for example in Zurich and in Chicago - but he always declined with thanks (for more on his transatlantic connections within the religious-social movement, including Leonhard Ragaz and Walter Rauschenbusch, see Noth 2010). He wanted to stay in his ministry in the city of Zurich, which he had started in 1902. He stayed with the same church congregation until 1939, the year when Freud and Bleuler both died.

In 1913 Pfister wrote one of the first (pedagogical) textbooks on psychoanalysis, to which Freud contributed a preface (Pfister 1913; Freud 1913). In this book, Freud expressed his conviction that psychoanalysis was not primarily for physicians. In 1915 the book was translated into English and published in London, and in 1917 it was published in New York.

Pfister was acquainted with the main psychoanalysts of the Psychiatric Clinic of the University of Zurich - the "Burghölzli" — which was the very first academic setting where Freud's new ideas were fostered. Pfister was in contact with Eugen Bleuler (born in 1857 and thus the same age as Freud), who was the director of the Burghölzli and who invented the terms schizophrenia (replacing Kraepelin's dementia praecox) and ambivalence. ${ }^{1}$ Carl Gustav Jung served Pfister as a supervisor, Ludwig Binswanger had lived in Pfister's house for a while, and Pfister went through an analysis with Franz Riklin, who was Jung's cousin.

In 1919, Pfister was one of the founders of the Swiss Psychoanalytic Association. Almost 10 years later, in 1928, a schism arose, and Pfister was a main actor in this conflict. We will publish the memorandum that is the 27-page-long summary of the reasons why a group of medical doctors founded their own medical Psychoanalytic Association (Noth 2013). Differing understandings on the question of lay analysis and on the correct practice of psychoanalysis were behind this move. It's a 27-page letter of complaint against Pfister!

Pfister was a prolific writer and contributed a huge number of books and articles on a wide variety of topics (Nase 1993). In the States, he's mainly still present in the form of the Oskar Pfister Award, which the American Psychiatric Association (APA) gives away once a year (recipients have included Oliver Sacks, Viktor Frankl, Ann Ulanov, and Ana-Maria Rizzuto).

This concludes our very brief notes on the charismatic, remarkable Oskar Pfister.

\section{The detective story}

Despite all his investigations in an effort to make psychoanalysis useful as a therapeutic method for pastoral care, and despite his many publications, even in Switzerland Oskar Pfister was as good as forgotten - even though Freud himself, writing to Pfister in February 1909, said, "I am very much struck by the fact that it never occurred to me how extraordinarily helpful the psychoanalytic method might be in pastoral work (but that is surely accounted for by the remoteness from me, as a wicked pagan, of the whole system of ideas)" (Freud and Pfister 1963, p. 10).

In 2006 - the 150th anniversary of Freud's birth - every newspaper was full of him in all variations: Freud and the brain, Freud and his chow-chows, Freud and Nietzsche, Freud in

\footnotetext{
${ }^{1}$ The Swiss National Science Foundation is funding the publication of the letters between Freud and Bleuler. See http://p3.snf.ch/project-124483.
} 
Tibet, etc. In Vienna every wall, every free space was plastered with ads quoting Freud. Against this background, it was astonishing that in this jubilee year not one single conference in Europe was devoted to the extraordinary friendship between the atheist and the pastor. In order to remedy the omission of this special friendship, we held a conference entitled "Sigmund Freud (1856-1939) — Oskar Pfister (1873-1956): The Beginnings of the Theological Reception of Psychoanalysis in Switzerland", which took place at the University of Bern. Using accessible sources, the participants in the conference brought new insights to bear on the relationship between Freud and Pfister and on Pfister's concept of analytic pastoral care. The lectures were published in 2007, with the support of the Sigmund Freud Center in Bern, as part of the series "Practical Theology Today", published by Kohlhammer-Verlag, Stuttgart (Noth and Morgenthaler 2007).

At the 2007 conference, we had to rely, like everybody else, on the selection of letters published by Ernst L. Freud and Heinrich Meng in 1963 and - in German — again in 1980 (Freud and Pfister 1980) by Fischer-Verlag, which also appeared in an English translation that same year published by Basic Books, New York. This edition did not contain all the letters between Freud and Pfister, and it included only excerpts of some. The editors' criteria for selection of the letters is by no means clear. Significant details are lacking, and there are also some incorrect translations (Noth and Jonte-Pace 2011).

Ernst Freud writes in his preface:

We had hoped to publish [Freud's] correspondence with Pfister in its entirety but, though Freud's original letters have survived, Pfister's have not. Some were destroyed by Freud at Pfister's wish (see letter dated 1.6.1927), and others perished in the hazards of emigration. However, surviving shorthand notes of Pfister's have made it possible to reconstruct his letters and hence to fill in a number of important gaps. The correspondence began in 1909 and ended in 1937. . . . It consisted altogether of 134 items by Freud, of which nearly a hundred, mostly unabbreviated, are reproduced here. (Freud and Pfister 1963, p. 7)

The editors chose to publish 99 letters of Freud and only 31 of Pfister; and the latter were often excerpted. Thus, the ratio of writings by Freud to Pfister ended up to be 3 to 1 ! This was one of the reasons that led to the incorrect impression that Pfister was just an adept, a fan of Freud who simply took over his ideas and applied them to pastoral care instead of being a serious discussion partner of Freud.

Ernst L. Freud writes in his preface, "The correspondence began in 1909 and ended in 1937'. If you look at his and Heinrich Meng's edition, you'll see that Freud's last letter to Pfister is from 1937, but Pfister's last published letter to Freud is from 1938. And we have now found several that are from 1939. In other words, the dominant Freudocentric perspective shaped our main source - the 1963 edition of the letters - and that influenced our understanding of the friendship between these two men.

The first step was to find out where Freud's other letters to Pfister were held, the ones that had not been published. That was easy: in the Freud Collection at the Library of Congress. What was less easy was to learn how to read Freud's handwriting and how to transliterate it.

What really bothered us was the information regarding the "surviving shorthand notes of Pfister's" - where were these notes? Everybody thought they must be in the central library of Zurich where Pfister's legacy is kept. They weren't! They seemed to have vanished.

Then, one day, Noth looked something up in Gay's biography on Freud (Gay 1988). Absolutely by accident (!), she somehow noticed the passage where Gay mentions that Freud advised Pfister not to study medicine as Pfister's father had done. This information was striking since it never shows up in the specific literature on Pfister. In the footnote at the 
end of the thick book, Gay wrote: "years later Pfister thanked Freud for telling him in 1912 not to go and study medicine," and as proof he cited "letter Pfister to Freud from June 14, 1927".

This letter was not in the published edition. Gay put in brackets as the source of his information "Sigmund Freud Copyrights, Wivenhoe." This was the piece of information that finally led - after a two-year search - to a typescript of the correspondence between Pfister and Freud held at the University of Essex, containing over 80 new or complete letters that had been reconstructed from fragmentary shorthand notes by Pfister, letters that had not been included in the Freud/Meng edition. The new edition has a third as many more of Freud's letters and over twice as many more of Pfister's letters than before. This changes the character of the correspondence. We see now that Pfister was much more critical of Freud's work than we had thought and that he was much more interested in analytic-technical questions than anybody had imagined.

\section{Case studies}

There are two patient case studies ${ }^{2}$ that are particularly important in the newly found letters. Each case spanned several years and therefore allows us to know much more about the history of the development of psychoanalysis, its technique, and its reception.

One case study deals with the couple Dr. Emil Oberholzer (1883-1958) and Dr. Mira Oberholzer-Gincburg (1884-1949) (see von Planta 2010) and is most important for the history of the psychoanalytic movement in Switzerland and for Pfister's position in it. It proves beyond doubt that the president of the recently founded medical association-Emil Oberholzer-as well as his wife were both in treatment with Freud and Pfister.

The other case study is a female patient whom Freud treated for almost 7 years. He called her his "grand-patient" and "chief tormentor". The Austrian psychoanalyst Ernst Falzeder put together the puzzle: Ms. A. in the correspondence between Freud and Abraham, Ms. C. in the correspondence between Freud and Jung, Ms. G. in the correspondence between Freud and Binswanger, and Ms. H. in the correspondence between Freud and Pfister are all Freud's patient Elfriede Hirschfeld (1873-?) (Falzeder 1995). Falzeder wrote: "During the time of her treatment the development of essential concepts occurred: the theory of technique (countertransference, the distinction between positive and negative transference, the similes of the surgeon and the mirror, resistance analysis, repetition compulsion, transference neurosis, working through, principle of abstinence)" (p. 98).

Freud treated Hirschfeld between 1908 and 1914. The new letters clearly confirm Falzeder's thesis: Freud was highly engaged with this patient, and the patient was "substantially involved" in the theoretical development of psychoanalysis. What Falzeder couldn't see clearly was the role Pfister played in this situation. Hirschfeld, who also had been in treatment with Jung and also had a diagnosis from Bleuler, went to Pfister in 1911. It was Freud who asked Pfister for help. A few months later, Pfister asked Freud: Did I make a technical mistake in her treatment? Freud replied, "Yes, you did! Two main faults: you wanted her to stay longer and you got emotionally too involved. I made the same mistakes earlier but learned not to do them any more." For some reason, Hirschfeld returned to Pfister later for more treatment.

In letters from Pfister in May 1920 we read sentences like: “Oh, Ms. Hirschfeld reminds me of your birthday and asks me to also congratulate you in her name”. Freud writes back

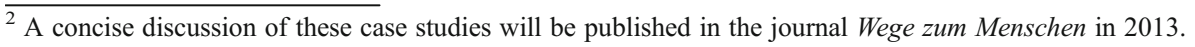


and says: "Say hello to Ms. Hirschfeld." In 1921 Pfister asks Freud to take her back in treatment because he's sure that Freud is the only one who will be able to help her because she feels more emotionally attached to him than to anybody else. In the end she, her husband, and her sister received treatment - not from Freud nor from Pfister, but from Binswanger. We see a whole confusing network of relationships and different constellations between patients and analysts, patients and patients, and analysts and analysts; analysts talking about their same patients; and patients bringing messages from one analyst to the other.

Most important are the technical issues: We see now how not only difficult but also beloved patients - patients who frightened their therapists because of the feelings they awoke in them-were shoved back and forth and from one to the other like hot potatoes. Freud's understanding of countertransference, his abstinence rule, etc., have to be seen in the context of the practical experiences he himself had, especially in this time period and with Elfriede Hirschfeld, who wanted to be loved and seeked fulfillment.

The development of psychoanalysis and its concepts and techniques-let's call it the "shared wisdom" (Cooper-White 2004) —are co-constructed in the intersubjective space of a specific triangle composed of the therapeutic relationship between analyst and patient, of the patient's relationship with other patients, and of the collegial relationship between friends (in our case, between Freud and Pfister). Pfister was a very committed follower of Freud - they shared much wisdom together-and in some respects they even shared in their understanding of religion.

\section{Friendship and the question of religion}

The plot of the best story that can be told about Freud and Pfister is hidden in the title of our presentation; it is a story about the steady, sometimes stormy, somehow strange friendship between Freud and Pfister, and don't forget this: It is a story about the friendship between an atheist and a holy man who strongly believed in a loving God; the friendship between a medical doctor and a pastor; between a Jew and a Christian; between the sober founder of psychoanalysis who was sternly opposed by his opulent Catholic environment and a Protestant adherent in Zurich, the city of Zwingli, who helped to break the hegemony of Catholicism in Europe. Why did this friendship not break apart?

Well, it is difficult to find the answer to this question. The acid test these friends went through might have been their experiences with and ideas about religion. Pfister visited Freud for the last time in 1936. These were Freud's last words to Pfister: "The fact that you still have religion, I can't forgive you." Why did this friendship last in spite of the differences in religious orientation? And what can this tell us about Freud's position with regard to religion? There are five points we would like to highlight:

First, the friendship was not just a friendship between Freud and Pfister; it was also a friendship between Pfister and the family Freud. This is well documented by the new letters. Anna Freud, in her foreword to the English edition of the letters, speaks vividly of Pfister when she says:

In him there was nothing of the almost passionately impatient enthusiasm for science which caused other pioneers of analysis to regard time spent at the family table only as an unwelcome interruption of their theoretical and clinical discussions. On the contrary, his human warmth and enthusiasm, his capacity for taking a lively part in the minor events of the day, enchanted the children of the household, and made him at all times a most welcome guest, a uniquely human figure in his way. To them, as Freud 
remarked, he was not a holy man, but a kind of Pied Piper of Hamelin, who had only to play on his pipe to gather a whole host of willing young followers behind him. (Freud and Pfister 1963, p. 11)

One could elaborate on this point. Pfister grew up without a father, was unhappy in his first marriage, and his relationship with his son was not without tension, as the correspondence also shows.

But this is not the whole story. Let us add a second point with regard to religion in particular. There were at least three areas where Freud's and Pfister's interest in and their critique of religion were in some ways overlapping. They both went through a European humanistic education. They both were keenly interested in culture and its history. They both knew how important religion was in culture. And they both could play with words alluding to this shared background. Freud wrote a postcard (July 14, 1910) in which he briefly mentioned his "devotions" when he visited the temple at Segesta. He knew that Pfister would understand what type of devotion he was referring to in the ironic turn of his words.

Part of this common culture is the Judeo-Christian tradition with its narratives. Freud refers at certain points of the correspondence to these religious traditions. "Building the temple with one hand and with the other, wielding weapons against those who would destroy it - strikes me as a reminiscence from Jewish history" (letter from Freud to Pfister, October 16, 1910, in Freud and Pfister 1963, p. 45-46) - this is how Freud describes his difficult position at a time when the first signs of the impending break with Jung were surfacing. Pfister, of course, knew that Freud was alluding to Ezra and Nehemiah who brought Israel out of slavery in Babylon back into the promised land and rebuilt Jerusalem's wall and the temple (Neh. 4:16ff.). This is a telling metaphor. Freud understood himself as leader in the same way Jews of former generations were leaders. Pfister himself is not at a loss when it comes to comparing Freud with religious leaders of the Christian tradition. He compares Freud to Jesus and Luther (July 9, 1914, again from a new letter). In this way, their common heritage with its religious narratives was in some ways a reservoir of bricks out of which they built bridges here and there in the correspondence. ${ }^{3}$

This sensibility in relation to the history of present forms of religion was perhaps important with regard to a third point: Freud lived in Vienna. Catholicism was the Christian confession of his environment. After 1930, this became a deadly menace to Freud and psychoanalysis when it merged with National Socialism. Pfister was not only a prominent member of the "Swiss fraction", as Freud once called the group of Jung, Bleuler, Binswanger, and Pfister, who were so important for their early support of psychoanalysis. He also lived in Zurich, the city of Zwingli, the founder of the deviant Reformed tradition, and was a respectable representative of this church opposed to Catholicism and Rome. And he lived in Switzerland - a country where a flight from National Socialism could lead.

The title of the English edition of the letters is Psychoanalysis and Faith. This could be understood as suggesting that there was pure psychoanalysis on Freud's side and pure faith on Pfister's. But Freud and Pfister agreed in some ways in their critique of religion or at least - as far as Pfister is concerned - in their critique of certain expressions of religion. Religion can hinder human development and the free use of reason. Religion can make people sick. Religion in its ritualized forms operates on the collective level in the same ways as neurotic symptoms do on the individual level. In Pfister's analyses of Zinzendorf, Paul,

\footnotetext{
${ }^{3}$ Marthe Robert (1973), in her book d'Oedipe à Moise, hints at the importance of Freud's refering to the myths of antiquity - in particular the myth of Oedipus - for the early acceptance of psychoanalysis in the Swiss group. "Solid classicism", as she calls it, was a common ground and opened doorways between the suspect Jewish and the dominant Christian culture.
} 
and also less well-known believers such as the mystic Margaretha Ebner-fine examples of "psychohistoire avant la lettre" - he shows his ability and intrepidness in analysing the foundational religious traditions of Christianity and his stern opposition to every form of combined superstition and stupidity. Freud agrees with Pfister's interpretations. He writes (letter from Freud to Pfister, June 18, 1911, in Freud and Pfister 1963, p. 52), with regard to an article Pfister has just published: "The beginning of the analysis of the crazy 'speaking with tongues' is terribly amusing". They both also agree that Eros was important in the lives of all the founders of religion (letter from Freud to Pfister, June 17, 1910, in Freud and Pfister 1963, pp. 40-41), and they agree-explicitly in opposition to Jung - that religion can be a sublimation of primary drives (new letter from July 1914). In addition, Freud did not deny Pfister's thesis that true religion can be a defense against neurosis, as Meng writes in his preface to the edition, "though he thought that in this loveless world it was a rarity and therefore not a thing not to be depended on" (Freud and Pfister 1963, p. 10).

This is the fourth point: It is very interesting to see how Freud and Pfister handle their differences during the "high noon" of their dispute about religion, in the years 1927/28. Freud published his critique of religion, The Future of an Illusion, which became very well known and which has affected psychoanalysis and its stance towards religion for decades. Pfister wrote a counterplea, The Illusion of a Future, a very concise critique of Freud's critique and its presuppositions. The Future of an Illusion and The Illusion of a Future: this chiasm points precisely to the fine and incisive boundary between the two. They each speak of the same thing and of something totally different. And they each use a language of mutual respect when they deal with these differences. The conflict is carefully prepared. Freud informs Pfister of his new book in his letter of October 10, 1927 (in Freud and Pfister 1963, p. 109): "I had been wanting to write it for a long time, and postponed it out of regard for you, but the impulse became too strong." Pfister identifies with the aggressor in his habile reply: "A powerful-minded opponent of religion is certainly of more service to it than a thousand useless supporters" (letter from Pfister to Freud, October 21, 1927, in Freud and Pfister 1963, p. 110). Freud starts his next letter with the following words: "Such is your magnanimity that I expected no other answer to my 'declaration of war'... We know that by different routes we aspire to the same objectives for poor humanity [die armen Menschlein, an expression that cannot easily be translated]" (letter from Freud to Pfister, October 22, 1927, in Freud and Pfister 1963, pp. 112-113).

In the next letter - one of the longest letters in the correspondence-Pfister writes that he was surprised not to be more surprised by Freud's pamphlet, and he makes it clear that "I have always emphasized that psycho-analysis is the most fruitful part of psychology, but it is not the whole of the science of the mind, and still less a philosophy of life and the world." Pfister even insinuates: "You are certainly of the same view" (letter from Pfister to Freud, November 24, 1927, in Freud and Pfister 1963, p. 114). Freud concedes in the next letter: "Let us be quite clear on the point that the views expressed in my book form no part of analytic theory" (letter from Freud to Pfister, November 26, 1927, in Freud and Pfister 1963, p. 117). Freud says that he would be eager to publish Pfister's reply in the journal Imago and hopes "that in it you will specifically draw attention to our undisturbed friendship and your unshaken loyalty to analysis." The boundary is marked on both sides. The relationship stays. This is the basis for agreeing not to agree. Thus, The Illusion of a Future and The Future of an Illusion come to stand beside each other. Only the historical reception, meaning people's responses to these two books, created division and opposition, but the letters of Freud and Pfister succeeded in avoiding this division. The elective affinity of liberal humanism is stronger than the religious kindredship of religion. 
Darlene Ehrenberg (1974) showed how important the encounter at the intimate edge of relationship is for the analytical dialogue and for the unfolding of maximum growth and change. The therapeutic way leads along this intimate edge, "that point of maximum and acknowledged contact at any given moment in a relationship without fusion, without violation of the separateness and integrity of each participant" (p. 424). This provides the kind of experience "in which the participants' awareness expands via the relationship as they clarify what they evoke and what they respond to in each other. This can only move in the direction of new experiences of mutuality and intimacy, and towards increasing self knowledge and individuality." A friendship is not an analytical relationship, a correspondence not a therapy. But nevertheless, we think the correspondence moves in some ways along this intimate edge of relationship and shows signs of transference and countertransference, symbolic densification, displacements of anxieties, and all the rest psychoanalysis is dealing with - but also a very real interaction in written words. The reflective interpretation of this process by both Freud and Pfister confers to the correspondence its floating, playful, and exigent character. And this precisely helps the two to become more intimate with their own experience, in this case also their experience of religion. As Freud writes: "There is a special value in personal relations which shared work and interests cannot completely make good; and we two, at this moment when we have become aware of the ultimate, fundamental differences between us, have particular occasion — and, I hope, inclination - to foster such relations" (letter from Freud to Pfister, February 7, 1930, in Freud and Pfister 1963, p. 132).

The fifth point is a short conclusion. Freud's religion has increasingly become a topic of scientific discussion, on both sides of the Atlantic. Some of Freud's writings are especially interesting in this respect, such as Moses and Monotheism, but also Freud's fascination for Michelangelo's Moses, which shows his identification with this former leader of the Jewish people. We suppose the correspondence between Freud and Pfister is telling us in some ways a similar story. Let us put it bluntly: Freud's friendship with Pfister lasted not in spite of their differences in religion, but because of these differences. Freud knew how deeply rooted cultural identities - including his own Jewish identity-are in religious traditions. Pfister also fascinated Freud because he managed to reconcile being critical and analytical about his own religious tradition and remain a believer. To say it in a quieter voice: This fascination might have been an important ingredient in the 30-year friendship between Freud, the atheist, and Pfister, the believer.

\section{References}

Boisen, A. T. (1960). Out of the depths. An autobiographical study of mental disorder and religious experience. New York: Harper \& Brown.

Cooper-White, P. (2004). Shared wisdom: Use of the self in pastoral care and counseling. Minneapolis: Fortress Press.

Ehrenberg, D. B. (1974). "The intimate edge" in therapeutic relatedness. Contemporary Psychoanalysis, 10, $423-437$.

Falzeder, E. (1995). Meine Großpatientin, meine Hauptplage. Ein bisher unbeachteter Fall Freuds und die Folgen. Jahrbuch der Psychoanalyse, 34, 67-100.

Freud, S. (1913). Geleitwort zu: Pfister, O. (1913): Die Psychanalytische Methode, Leipzig, IV-VI, Gesammelte Werke X, 448-450.

Freud, S. (2001). In J. Strachey (Ed.), Moses and monotheism. Standard Edition of the complete psychological works of Sigmund Freud, Vol. 23. London: Hogarth.

Freud, S., \& Pfister, O. (1963). Psychoanalysis and faith: The letters of Sigmund Freud and Oskar Pfister. E. L. Freud \& H. Meng (Eds.), E. Mosbacher (Trans.) New York: Basic Books. 
Freud, S., \& Pfister, O. (1980 [1963]). Briefe. 1909-1939. E. L. Freud \& H. Meng, Eds. Frankfurt a. M.: Fischer.

Gay, P. (1988). Freud: A life for our time. New York: W. W. Norton.

Nase, E. (1993). Oskar Pfisters Analytische Seelsorge. Theorie und Praxis des ersten Pastoralpsychologen, dargestellt an zwei Fallstudien. Berlin: de Gruyter.

Noth, I. (2007). "Deine Ehrfurcht und meine Liebe": Oskar Pfister (1873-1956) und Albert Schweitzer (1875-1965). In I. Noth \& C. Morgenthaler (Eds.), Seelsorge und Psychoanalyse (Praktische Theologie heute, Vol. 89, pp. 46-58). Stuttgart: Kohlhammer.

Noth, I. (2008). Albert Schweitzer und die Psychoanalyse. Luzifer-Amor. Zeitschrift zur Geschichte der Psychoanalyse, 43, 133-143.

Noth, I. (2010). Freuds Bleibende Aktualität: Psychoanalyserezeption in der Pastoral-und Religionspsychologie im Deutschen Sprachraum und in den USA. Stuttgart: Kohlhammer.

Noth, I. (Ed.). (2013). Sigmund Freud - Oskar Pfister. Briefwechsel 1909-1939. Zürich: Theologischer Verlag Zürich. (in press)

Noth, I., \& Jonte-Pace, D. (2011). Psychology of religion and gender. In I. Noth, C. Morgenthaler, \& K. J. Greider (Eds.), Pastoral psychology and psychology of religion in dialogue (Praktische Theologie heute, Vol. 115, pp. 183-193). Stuttgart: Kohlhammer.

Noth, I., \& Morgenthaler, C. (Eds.). (2007). Seelsorge und Psychoanalyse (Praktische Theologie heute, Vol. 89). Stuttgart: Kohlhammer.

Pfister, O. (1913). Die psychanalytische Methode: Eine erfahrungswissenschaftlich-systematische Darstellung. Leipzig: Klinkhardt.

Robert, M. (1974). D’Oedipe à Moise: Freud et la conscience Juive. Paris: Calmann-Lévy.

von Planta, V. (2010). “Analysiere nie wieder einen jungen Menschen wie mich . ..”: Emil Oberholzer und Mira Oberholzer-Gincburg, ein Russisch-Schweizerisches Analytikerpaar in der ersten Hälfte des 20. Jahrhunderts. Luzifer-Amor. Zeitschrift zur Geschichte der Psychoanalyse, 45, 70-104. 